\title{
Double blind controlled trial of oral vancomycin as adjunctive treatment in acute exacerbations of idiopathic colitis
}

\author{
R J DICKINSON, H J O'CONNOR, I PINDER, I HAMILTON, \\ D JOHNSTON, AND A T R AXON \\ From the Gastroenterology Unit and University Department of Surgery, General Infirmary \\ at Leeds, Leeds
}

SUMMARY A prospective double blind trial of vancomycin $v s$ placebo was undertaken in 40 consecutive adult patients with exacerbation of idiopathic colitis (33 ulcerative colitis, seven Crohn's disease). Vancomycin or placebo (500 $\mathrm{mg}$ six hourly) was given for seven days in addition to routine medical therapy. Although there was no significant overall difference in outcome between the two groups, there was a trend towards a reduction in the need for operative intervention in patients with ulcerative colitis treated with vancomycin compared with controls. The efficacy of vancomycin was not attributable to its known action against $C$ difficile, which was not isolated from any of the patients. The data suggest that microbiological factors may play a part in the pathogenesis of ulcerative colitis and that further studies using antimicrobials are desirable.

Acute exacerbations of idiopathic colitis (ulcerative colitis and Crohn's disease) in many respects resemble the clinical picture found in acute infective colitis and this suggests that microorganisms may have some aetiological role in the pathogenesis of idiopathic colitis. In spite of this and although the use of tetracycline has been advocated as part of a treatment package ${ }^{1}$ controlled trials of antimicrobials in this condition have been limited to the sulphonamides. ${ }^{23}$ Vancomycin is a non-absorbable antibiotic active against Gram-positive organisms, ${ }^{4}$ attaining a high concentration in faeces when given orally. It has been successfully used in treating pseudomembranous colitis caused by Staphylococcus aureus and $C$ difficile which are highly sensitive to it in vitro. ${ }^{56}$ While there are sound bacteriological reasons why vancomycin should be of value in disease caused by either of these organisms, there remains a possibility that its efficacy may result from other effects on the faecal flora. An additional justification for a trial of vancomycin in exacerbations of idiopathic colitis is that $C$ difficile enterotoxin has been implicated as

Address for correspondence: Dr H J O'Connor, Research Registrar. Gastroenterology Unit, General Infirmary at Leeds, Leeds LS1 3EX.

Received for publication 30 January 1985 an aggravating factor in some patients with this disease. $^{78}$

This paper describes a double blind controlled trial of oral vancomycin in consecutive patients admitted to hospital in acute exacerbation of idiopathic colitis. The aims of the trial were to determine whether vancomycin was of value as an adjunct to the routine treatment of exacerbations and, if so, whether this benefit could be related to an increased faecal carriage of $C$ difficile. The study was approved by the local ethical committee.

\section{Methods}

PATIENTS

From March 1979 to December 1981, adult patients admitted to the General Infirmary at Leeds with acute idiopathic colitis were interviewed and their informed consent to enter the trial was obtained. They were questioned and examined by an independent assessor and underwent sigmoidoscopy, barium enema, and rectal biopsy. The patient was entered into the trial provided that typical changes of idiopathic colitis ${ }^{9}$ were found in the rectum and extended into the sigmoid colon beyond the limit of the sigmoidoscope, or typical radiological changes were found at barium enema ${ }^{10}$ and that the disease 
satisfied the criteria for inclusion into the moderate, or severe categories of Truelove and Witts. ${ }^{11}$ Patients were randomised to receive vancomycin or placebo $500 \mathrm{mg}$ six hourly for seven days according to a code held by the central pharmacy and which was not known to the attending physicians. All patients received bed rest and prednisolone $40 \mathrm{mg} /$ day in divided doses; infusions of blood, albumin and electrolytes were given as required to maintain the blood haemoglobin concentration above $12 \mathrm{~g} / \mathrm{dl}$ and the plasma albumin concentration greater than $36 \mathrm{~g} / \mathrm{l}$. Routine haematological and biochemical measurements were made every two days and stool frequency was recorded daily with details of consistency and the presence or absence of blood. The prednisolone dosage was reduced stepwise in all patients by $5 \mathrm{mg}$ decrements every three days provided that all the following conditions applied throughout the previous 72 hour period; three or fewer bowel movements per day, absent to mild pain or malaise, and weight loss less than $1 \mathrm{~kg}$. In patients who failed to fulfil these criteria, the dosage of prednisolone was not reduced.

At the time of admission to hospital, faecal samples were sent to the routine laboratory for bacteriological analysis and conventional bacterial pathogens were sought including Staphylococcus aureus and $C$ difficile. ${ }^{12}{ }^{13} C$ difficile toxin was assayed on Hep-2 cell monolayers (Flow Laboratories Limited, Rickmansworth, UK) using the technique described by George. ${ }^{14}$

The trial end point was reached either when the patient was discharged from hospital or when surgery was carried out. The indications for surgical intervention were: severe continuous or worsening symptoms while on medical therapy and/or the occurrence of life threatening complications. The decision to operate was taken jointly by the physician in charge of the case and an independent surgeon, neither of whom had any knowledge as to whether active or placebo vancomycin had been prescribed.

\section{Results}

PATIENT SAMPLE AND DIAGNOSIS

Forty patients were admitted to the trial and their age, sex, diagnosis and duration, and extent of disease are shown in Table 1 . Twenty two patients were randomly allocated to receive active vancomycin while 18 received placebo. Eighteen of the vancomycin group had ulcerative colitis and four had Crohn's disease. Among the placebo patients, 15 had ulcerative colitis and three Crohn's disease. The majority of the patients in both groups were in exacerbation of established disease which had failed
Table 1 Details of patient groups

\begin{tabular}{lll}
\hline & Vancomycin & Placebo \\
\hline Patients (no) & 22 & 18 \\
Men & 11 & 12 \\
Mean age ( \pm SD) (yr) & $39 \cdot 1 \pm 13 \cdot 2$ & $35 \cdot 4 \pm 12 \cdot 4$ \\
$\begin{array}{l}\text { Mean duration of disease } \\
\quad( \pm \text { SD) (yr) }\end{array}$ & $6 \cdot 1 \pm 6 \cdot 5$ & $7 \cdot 4 \pm 4 \cdot 6$ \\
$\quad$ Ulcerative colitis & 12 & 8 \\
$\quad$ Total & 2 & 1 \\
$\quad$ Subtotal & 4 & 6 \\
$\quad$ Proctosigmoiditis & 2 & 3 \\
$\quad$ Crohn's disease & 2 & \\
$\quad$ Total & & \\
\hline
\end{tabular}

to settle on outpatient therapy and only five patients (four in the vancomycin group and one in the placebo group) presented within a year of onset of their disease. In the vancomycin group there were 11 men and 11 women with a mean age of $39 \cdot 1 \pm 13 \cdot 2$ years and the mean duration of disease was $6 \cdot 1 \pm 6 \cdot 5$ years. In the control group there were 12 men and six women with a mean age of $35 \cdot 4 \pm 12.4$ years and the mean duration of disease was $7 \cdot 4 \pm 4 \cdot 6$ years.

\section{EXTENT OF DISEASE}

Of the patients in the vancomycin group, 14 patients (12 ulcerative colitis, two Crohn's disease) had total colonic involvement as compared with 11 in the placebo group (eight ulcerative colitis, three Crohn's disease). One of the placebo patients (no 35) had small bowel involvement as well. Two patients with ulcerative colitis in the vancomycin group and one in the placebo group had subtotalcolonic involvement which was defined as disease extending proximal to the splenic flexure, but not involving the hepatic flexure at barium enema examination. Four patients with ulcerative colitis in the vancomycin group and six in the placebo group had proctosigmoiditis only.

\section{OUTCOME OF TRIAL}

Overall there was no significant difference in outcome between the patient groups. Table 2 shows that four patients receiving vancomycin and seven receiving placebo came to surgery, the details and indications for which are given in Table 3. All but one of the patients needing urgent operation in each group were treated surgically at an interval of 12-46 days after admission. Though the primary aim of the study was to evaluate the role of oral vancomycin as adjunctive treatment in acute exacerbations of idiopathic colitis irrespective of whether because of ulcerative colitis or Crohn's disease, nevertheless, if 
Table 2 Details of each patient included in the trial and their outcome

\begin{tabular}{|c|c|c|c|c|c|c|c|c|}
\hline No & Age & Sex & Duration & Diagnosis & Extent & Severity & $\begin{array}{l}\text { Short term } \\
\text { outcome }\end{array}$ & Long term outcome \\
\hline \multicolumn{9}{|c|}{ Vancomycin patients } \\
\hline 1 & 58 & $\mathrm{~F}$ & $4 \mathrm{~m}$ & UC & PS & Severe & Settled & 1 admission at 1 year, mild attack \\
\hline 2 & 31 & M & $5 \mathrm{yr}$ & UC & Total & Severe & Settled & 1 mild attack at 18 months \\
\hline 5 & 36 & $\mathrm{~F}$ & $7 \mathrm{yr}$ & UC & PS & Severe & Settled & Surgery at 6 months \\
\hline 7 & 30 & $\mathbf{M}$ & $6 \mathrm{yr}$ & UC & Total & Moderate & Settled & Surgery at 3 months \\
\hline 8 & 36 & M & $5 \mathrm{yr}$ & UC & Total & Severe & Settled & Surgery at 3 months with fulminant attack \\
\hline 9 & 31 & M & $1 \mathrm{yr}$ & UC & Total & Moderate & Settled & Remission \\
\hline 11 & 36 & $\mathbf{M}$ & $2 \mathrm{yr}$ & UC & Subtotal & Moderate & Settled & Remission \\
\hline 13 & 40 & $\mathbf{F}$ & $6 \mathrm{~m}$ & UC & Total & Severe & Settled & 1 mild attack at 6 months \\
\hline 17 & 46 & $\mathbf{F}$ & $6 \mathrm{yr}$ & UC & PS & Moderate & Surgery & - \\
\hline 18 & 45 & $\mathbf{M}$ & $1 \mathrm{yr}$ & UC & Total & Severe & Settled & 1 severe attack at 9 months \\
\hline 19 & 55 & $\mathbf{M}$ & $4 \mathrm{yr}$ & UC & Total & Moderate & Settled & Remission \\
\hline 20 & 19 & $\mathrm{~F}$ & $4 \mathrm{yr}$ & UC & Total & Moderate & Settled & Remission \\
\hline 22 & 34 & $\mathrm{~F}$ & $3 \mathrm{yr}$ & UC & Total & Moderate & Settled & Remission \\
\hline 25 & 30 & $\mathbf{M}$ & $12 \mathrm{yr}$ & $\mathrm{CC}$ & Patchy & Severe & Settled & Mild continuous symptoms \\
\hline 26 & 43 & $\mathbf{M}$ & $14 \mathrm{yr}$ & $\mathrm{CC}$ & Total & Moderate & Settled & Remission \\
\hline 28 & 79 & $\mathrm{~F}$ & $27 \mathrm{yr}$ & UC & Total & Severe & Settled & 1 mild attack at 4 months \\
\hline 30 & 30 & $\mathbf{M}$ & $3 \mathrm{yr}$ & UC & Total & Severe & Surgery & - \\
\hline 32 & 37 & $\mathbf{F}$ & $10 \mathrm{yr}$ & UC & Total & Moderate & Settled & Remission \\
\hline 35 & 28 & $\mathrm{~F}$ & $4 \mathrm{yr}$ & $\mathrm{CC}+\mathrm{SB}$ & Total & Severe & Surgery & - \\
\hline 36 & 54 & $\mathbf{M}$ & $17 \mathrm{yr}$ & $\mathrm{CC}+\mathrm{SB}$ & Patchy & Severe & Surgery & - \\
\hline 38 & 26 & $\mathrm{~F}$ & $4 \mathrm{~m}$ & UC & Subtotal & Moderate & Settled & 1 admission at 3 months \\
\hline 39 & 35 & $\mathrm{~F}$ & $10 \mathrm{~m}$ & UC & PS & Moderate & Settled & Remission \\
\hline \multicolumn{9}{|c|}{ Placebo patients } \\
\hline 3 & 64 & $\mathbf{M}$ & $8 \mathrm{yr}$ & UC & Total & Severe & Surgery & - \\
\hline 4 & 28 & $\mathbf{F}$ & $3 \mathrm{yr}$ & UC & PS & Severe & Surgery & - \\
\hline 6 & 39 & $\mathbf{F}$ & $14 \mathrm{yr}$ & UC & Total & Severe & Surgery & - \\
\hline 10 & 39 & M & $8 \mathrm{yr}$ & UC & Total & Moderate & Surgery & - \\
\hline 12 & 33 & $\mathbf{M}$ & $3 \mathrm{yr}$ & $\mathrm{CC}$ & Total & Moderate & Settled & Remission \\
\hline 14 & 18 & $\mathbf{M}$ & $4 \mathrm{yr}$ & UC & PS & Severe & Surgery & - \\
\hline 15 & 36 & $\mathbf{M}$ & $13 \mathrm{yr}$ & UC & PS & Moderate & Settled & Remission \\
\hline 16 & 33 & $\mathbf{M}$ & $8 \mathrm{yr}$ & UC & Total & Moderate & Surgery & - \\
\hline 21 & 24 & $\mathrm{~F}$ & $6 \mathrm{~m}$ & $\mathrm{CC}$ & Total & Severe & Settled & Remission \\
\hline 23 & 17 & M & $10 \mathrm{yr}$ & UC & Total & Severe & Surgery & - \\
\hline 24 & 39 & $\mathbf{M}$ & $8 \mathrm{yr}$ & UC & Total & Severe & Settled & 1 mild attack at 6 months \\
\hline 27 & 25 & $\mathbf{M}$ & $8 \mathrm{yr}$ & UC & Total & Severe & Settled & Surgery at 3 months after discharge \\
\hline 29 & 32 & $\mathbf{M}$ & $12 \mathrm{yr}$ & UC & PS & Moderate & Settled & Remission \\
\hline 31 & 41 & $\mathbf{M}$ & $17 \mathrm{yr}$ & UC & PS & Moderate & Settled & Remission \\
\hline 33 & 44 & $\mathbf{F}$ & $2 \mathrm{yr}$ & UC & Subtotal & Moderate & Settled & Remission \\
\hline 34 & 27 & $\mathbf{F}$ & $2 \mathrm{yr}$ & UC & PS & Moderate & Settled & Severe attack at 4 months - surgery \\
\hline 37 & 60 & $\mathbf{M}$ & $4 \mathrm{yr}$ & $\mathrm{CC}$ & Total & Severe & Settled & 1 moderate attack at 4 months \\
\hline 40 & 39 & $\mathbf{F}$ & $8 \mathrm{yr}$ & UC & Total & Moderate & Settled & Remission \\
\hline
\end{tabular}

$\mathrm{UC}=$ ulcerative colitis. $\quad \mathrm{CC}=\mathrm{Crohn}$ 's colitis. $\quad \mathrm{SB}=$ small bowel. $\quad \mathrm{PS}=$ proctosigmoiditis.

the patients with ulcerative colitis (by far the largest patient subgroup) are considered separately, then two of 18 in the vancomycin group compared with seven of 15 in the control group came to surgery which is a trend (two-tailed Fisher's exact test, $p=0.057$ ) in favour of active vancomycin. All the patients in the trial were followed up after its completion for a minimum of one year (Table 2). Three in the vancomycin group and two in the control group have since come to colectomy. No complications attributable to the vancomycin or placebo were encountered in any of the patients studied.
BACTERIOLOGICAL STUdies

No patient was shown to have a conventional pathogen in their faecal samples. $C$ difficile was sought in 38 out of 40 patients and was found in none of them. In the first two patients in the trial, it was not sought for technical reasons. C difficile toxin was also sought in patients nos 3-12 and was negative in all instances.

\section{Discussion}

There are problems inherent in any therapeutic trial of patients with idiopathic colitis not only because of 
Table 3 Indications for surgery in each patient

\begin{tabular}{|c|c|c|c|}
\hline $\begin{array}{l}\text { Patient } \\
\text { no }\end{array}$ & Operation & $\begin{array}{l}\text { Day of } \\
\text { Operation }\end{array}$ & $\begin{array}{l}\text { Reason for } \\
\text { Operation }\end{array}$ \\
\hline \multicolumn{4}{|c|}{ Vancomycin group } \\
\hline 17 & Subtotal colectomy* & 44 & $\begin{array}{l}\text { Severe continuous } \\
\text { symptoms }\end{array}$ \\
\hline 30 & Subtotal colectomy* & 12 & $\begin{array}{l}\text { Toxic dilatation } \\
\text { of the colon }\end{array}$ \\
\hline 35 & Proctocolectomy & 7 & $\begin{array}{l}\text { Severe worsening } \\
\text { symptoms }\end{array}$ \\
\hline 36 & $\begin{array}{l}\text { Proctocolectomy and } \\
\text { ileal resection }\end{array}$ & 30 & $\begin{array}{l}\text { Severe continuous } \\
\text { symptoms }\end{array}$ \\
\hline \multicolumn{4}{|c|}{ Placebo group } \\
\hline 3 & Proctocolectomy & 42 & $\begin{array}{l}\text { Severe continuous } \\
\text { symptoms }\end{array}$ \\
\hline 4 & Subtotal colectomy* & 21 & $\begin{array}{l}\text { Toxic dilatation } \\
\text { of the colon }\end{array}$ \\
\hline 6 & Proctocolectomy & 12 & $\begin{array}{l}\text { Severe continuous } \\
\text { symptoms }\end{array}$ \\
\hline 10 & Subtotal colectomy* & 20 & $\begin{array}{l}\text { Severe continuous } \\
\text { symptoms }\end{array}$ \\
\hline 14 & Subtotal colectomy* & 4 & Toxic dilatation \\
\hline 16 & Subtotal colectomy* & 46 & $\begin{array}{l}\text { Severe continuous } \\
\text { symptoms }\end{array}$ \\
\hline 23 & Subtotal colectomy* & 38 & $\begin{array}{l}\text { Severe worsening } \\
\text { symptoms }\end{array}$ \\
\hline
\end{tabular}

* Including preservation of the rectum and mucous fistula.

its unpredictability, but also because there may be a marked variation in the duration, extent and severity of the disease, all of which may affect the response to therapy. ${ }^{11} 1516$ Thus the heterogeneity of our study population may present problems in interpretation of results, particularly in view of the small number of subjects involved. Likewise, a bias might result from the preponderance of patients with recent onset of disease (four out of five) falling by chance into the vancomycin group. Within these limitations, our results suggest that oral vancomycin may reduce the need for operative intervention in patients in exacerbation of ulcerative colitis. In view of the small number of patients with Crohn's disease, it is difficult to make any statement concerning the impact of vancomyin in this group.

There have been no previous controlled trials of antimicrobials in exacerbation of idiopathic colitis, except for those involving sulphasalazine ${ }^{23}$ nor have there been any previous studies involving vancomycin except in patients with idiopathic colitis complicated by infection with $C$ difficile enterotoxin. ${ }^{7}$ The reasons for the apparent benefit of vancomycin in patients with ulcerative colitis are unclear. Faecal culture for $C$ difficile was negative in the 38 patients in whom it was sought and, in addition, assay for its associated enterotoxin was negative in nine. Ideally, all 40 patients admitted to the study should have had faecal samples analysed for the presence of both $C$ difficile and $C$ difficile toxin. Nevertheless, these negative results are of interest as they suggest that the efficacy of vancomycin may relate to factor(s) other than faecal carriage of this pathogen, such as the known antimicrobial action of vancomycin on the Grampositive component of the faecal flora which is profuse in ulcerative colitis. ${ }^{17-19}$ To elucidate fully the mode(s) of action of vancomycin in ulcerative colitis would have required detailed microbiological analysis of faecal samples taken before and at intervals after therapy and this was beyond the technical scope of the present study. Indeed, it has been estimated that complete bacteriological characterisation of a single faecal sample may take up to one year to complete. ${ }^{20}$

It could be argued that the dose of vancomycin used was very large particularly in view of the cost of the drug $^{821}$ (vancomycin $500 \mathrm{mg}$ six hourly $\times 7$ seven days, current NHS price $=£ 315$ ). This criticism probably cannot be justified if vancomycin results in a reduction of the operation rate in colitis and it may be possible to administer the drug in a reduced dosage without losing its apparent benefit.

The negative results for $C$ difficile are of interest. Reports from Boston ${ }^{72}$ and Bristol ${ }^{23}$ have demonstrated faecal $C$ difficile enterotoxin in as many as $60 \%$ of severe exacerbations of idiopathic colitis. These findings are not, however, universal as, apart from the results of this study, Meyers et al ${ }^{24}$ found $C$ difficile enterotoxin in only four out of 44 patients with idiopathic colitis and related its presence not to disease activity but to the antimicrobial drugs these patients had taken previously. These differences in identification rate are unlikely to be due to method because both culture of $C$ difficile and the identification of its enterotoxin are now routine. Another explanation for the discrepancy might be prior antimicrobial treatment, but here the data are incomplete $^{8}$ and it would be insufficient on its own to explain the degree of difference observed.

Alternatively, different identification rates may relate to epidemiological factors. There is little doubt that outbreaks of $C$ difficile occur in hospitals and this might account for the apparent rarity of the organism in one hospital compared with another. ${ }^{8}$ 25-27 This seems the most likely explanation to account for the negative cultures obtained in this study and the surprisingly high identification rates described by Trnka and LaMont. ${ }^{7}$

Though additional prospective studies on larger numbers of patients are necessary to prove the efficacy of oral vancomycin in ulcerative colitis, the results of this trial show a possible role for this antimicrobial agent in the treatment of exacerbations of the disease. The observed efficacy of 
vancomycin was not attributable to its known action against $C$ difficile, but suggests a role for the faecal flora in the pathogenesis of ulcerative colitis.

We are grateful to Mrs Olive Bell for typing the manuscript.

\section{References}

1 Truelove SC, Reynell PC. Diseases of the digestive tract. 2nd ed. Oxford: Blackwell Scientific Publications, 1972.

2 Truelove SC, Watkinson G, Draper G. Comparison of corticosteroid and sulphasalazine therapy in ulcerative colitis. Br Med J 1962; 2: 1708-11.

3 Dick AP, Grayson MJ, Carpenter RG, Petrie A. Controlled trial of sulphasalazine in the treatment of ulcerative colitis. Gut 1964; 5: 437-42.

4 Garrod LP, Lambert HP, O'Grady F. Antibiotic and chemotherapy. 5th ed. Edinburgh: Churchill Livingstone, 1981: 234-6.

5 Khan MY, Hall WH. Staphylococcal enterocolitis treatment with oral vancomycin. Ann Intern Med 1966; 65: $1-8$.

6 Keighley MRB, Burdon DW, Arabi Y et al. Randomised controlled trial of vancomycin for pseudomembranous colitis and postoperative diarrhoea. $\mathrm{Br} \mathrm{Med} \mathrm{J}$ 1978; 2: 1667-9.

7 Trnka YM, LaMont JT. Association of Clostridium difficile toxin with symptomatic relapse in chronic inflammatory bowel disease. Gastroenterology 1981; 80: $693-6$.

8 Bartlett JG. Clostridium difficile and inflammatory bowel disease. Gastroenterology 1981; 80: 863-5.

9 Lennard-Jones JE, Lockhart-Mummery HE, Morson BC. Clinical and pathological differentiation of Crohn's disease and protocolitis. Gastroenterology 1968; 54: 1162-70

10 Marshak RH, Lundner MD. Radiologic diagnosis of chronic ulcerative colitis and Crohn's disease of the colon. In: Kirsner JB, Shorter RG, eds. Inflammatory bowel disease. Philadelphia: Lea and Febiger, 1975: 241-76.

11 Truelove SC, Witts LJ. Cortisone in ulcerative colitis. Final report on a therapeutic trial. $\mathrm{Br} M e d J$ 1955; 2: 1041-8.
12 Dickinson RJ, Dixon MF, Axon ATR. Staphylococcal enterocolitis and inflammatory bowel disease. J Clin Pathol 1980; 33: 604-5.

13 Hafiz S, Oakley CL. Clostridium difficile: isolation and characteristics. J Med Microbiol 1976; 9: 129-37.

14 George RH. A micro-method for detecting toxins in pseudomembranous colitis. J Clin Pathol 1979; 32: 303-4.

15 Driscoll RH, Rosenberg IH. Total parenteral nutrition in inflammatory bowel disease. Med Clin North Am 1978; 62: 185-201.

16 Truelove SC, Willoughby CP, Lee EG, Kettlewell MGW. Further experience in the treatment of severe attacks of ulcerative colitis. Lancet 1978; 2: 1086-8.

17 Seneca H, Henderson E. Normal intestinal bacteria in ulcerative colitis. Gastroenterology 1950; 15: 34-9.

18 Cooke EM. A quantitative comparison of the faecal flora of patients with ulcerative colitis and that of normal persons. J Path Bacterol 1967; 94: 439-44.

19 van der Wiel-Korstanje JA, Winkler KC. The faecal flora in ulcerative colitis. J Med Microbiol 1975; 8: 491-501.

20 Simon GL, Gorbach SL. Intestinal flora in health and disease. Gastroenterology 1984; 86: 174-93.

21 Teasley DG, Gerding DN, Olson M et al. Prospective randomised trial of metronidazole versus vancomycin for Clostridium difficile - associated diarrhoea and colitis. Lancet 1983; 2: 1043-6.

22 LaMont JT, Trnka YM. Therapeutic implications of Clostridium difficile toxin during relapse of chronic inflammatory bowel disease. Lancet 1980; 1: 381-3.

23 Bolton RP, Sheriff RJ, Read AE. Clostridium difficile associated diarrhoea: a role in inflammatory bowel disease? Lancet 1980; 1: 383-4.

24 Meyers S, Mayer L, Bottone E, Desmond E, Janowitz HD. Occurrence of Clostridium difficile toxin during the course of inflammatory bowel disease. Gastroenterology 1981; 80: 697-700.

25 Milligan ME, Rolfe RD, Finegold SM, George WL. Contamination of a hospital environment by Clostridium difficile. Curr Microbiol 1979; 3: 173-5.

26 Keighley MRB. Antibiotic-associated pseudomembranous colitis: pathogenesis and management. Drugs 1980; 20: 49-56.

27 Greenfield C, Burroughs A, Szawathowski M, Bass N, Noone P, Pounder RE. Is pseudomembraneous colitis infectious? Lancet 1981; 1: 371-2. 